\title{
Review of MicroRNA Proposed Target Genes in Oral Cancer. Part II
}

\author{
Antonia Kolokythas ${ }^{1,2,3}$, Michael Miloro ${ }^{1}$, Xiaofeng Zhou ${ }^{2,4}$ \\ ${ }^{1}$ Department of Oral and Maxillofacial Surgery, University of Illinois at Chicago, USA. \\ ${ }^{2}$ Center of Molecular Biology and Oral Diseases, College of Dentistry, University of Illinois at Chicago, USA. \\ ${ }^{3}$ Cancer Center, University of Illinois at Chicago, USA. \\ ${ }^{4}$ Department of Periodontics, College of Dentistry, University of Illinois at Chicago, USA.
}

\author{
Corresponding Author: \\ Antonia Kolokythas \\ Assistant Professor and Director of Research \\ Department of Oral and Maxillofacial Surgery \\ University of Illinois at Chicago \\ 801 S. Paulina Street, MC 835, Chicago, Illinois, 60612-7210 \\ USA \\ Phone: 312-996-1052 \\ Fax: 312-996-5987 \\ E-mail: ga1@uic.edu
}

\begin{abstract}
Objectives: Cancer is the product of alterations in oncogenes, tumour suppressor genes and most recently microRNA genes not as a single event or single change but rather as a multistep process. The role of microRNA genes in carcinogenesis is recently explored and appears to be an early event in the pathogenesis of this as well as other disease processes and occurs via gene regulation by their own products, the microRNAs. The purpose of this article was to review the literature concerning MicroRNA proposed target genes in oral cancer.

Material and Methods: A review of the available literature from 2000 to 2011 regarding the potential roles assumed by microRNAs in oral cancer was undertaken using PubMed, Medline, Scholar Google and Scopus. Keywords for the search were: microRNA and oral cancer and target genes, microRNA deregulation and oral cancer, microRNA and carcinogenesis in the head and neck/oral cavity. English language full length articles were reviewed.

Results: Several microRNAs deregulated in oral cancer have been functionally validated and their exact target genes have been identified. Furthermore the carcinogenesis pathways impacted by these alterations has been proposed for some of these microRNAs.

Conclusions: The expanding knowledge of specific roles of certain microRNAs is further contributing to our understanding of the complexity of tumour progression and behaviour. Consideration of this information and incorporation into treatment modalities through targeted therapy could potentially enhance our abilities to improve outcome especially when other established therapies have failed.
\end{abstract}

Keywords: oral cancer; head and neck cancer; microRNA; gene targeting; carcinogenesis tests.

Accepted for publication: 19 April 2010

To cite this article:

Kolokythas A, Miloro M, Zhou X. Review of MicroRNA Proposed Target Genes in Oral Cancer. Part II.

J Oral Maxillofac Res 2011 (Apr-Jun);2(2):e2

URL: http://www.ejomr.org/JOMR/archives/2011/2/e2/v2n2e2ht.pdf

doi: $10.5037 /$ jomr.2011.2202 


\section{INTRODUCTION}

Cancer is the product of alterations in oncogenes, tumour suppressor genes and most recently microRNA genes not as a single event or single change but rather as a multistep process [1-6]. The role of microRNA genes in carcinogenesis is recently explored and appears to be an early event in the pathogenesis of this as well as other disease processes. MicroRNAs mediate gene expression at the posttranslational level by degrading or repressing target messenger RNAs (mRNA) or by translational inhibition of target genes. The possibility that microRNA involvement in cancer is simply a reflection of loss of normal cellular identity that naturally accompanies malignant transformation has been entertained. The identification though of microRNA genes in regions of the genome that are consistently involved in chromosomal rearrangements in cancer cells and do not contain oncogenes or tumour suppressor genes signifies a causative event in carcinogenesis [7-9]. The significance of microRNAs in cancer is accentuated by the fact that they can function as oncogenes by down-regulating tumour suppressor genes or as tumour suppressor genes by down-regulating oncogenes. MicroRNA genes' up-regulation can be the result of amplification, deregulation of a transcription factor or demethylation of $\mathrm{CpG}$ islands in promoter regions. MircoRNA genes' function as tumour suppressors is regulated by deletions, epigenetic silencing or loss of expression of one or more transcription factors [1, 10-15].

The purpose of this article was to review the literature concerning MicroRNA proposed target genes in oral cancer.

\section{MATERIAL AND METHODS}

A review of the available literature from 2000 to 2011 regarding the potential roles assumed by microRNAs in oral cancer was undertaken using PubMed, Medline, Scholar Google and Scopus. Keywords for the search were: microRNA and oral cancer and target genes, microRNA deregulation and oral cancer, microRNA and carcinogenesis in the head and neck/oral cavity. English language full length articles were reviewed

\section{MicroRNAs as oncogenes and tumour suppressor genes}

The recognition that microRNAs can function as oncogenes came from studies on the microRNA-17 cluster that was found to be amplified in breast, stomach, lung, pancreatic cancers as well as B-cell lymphomas [16-25]. Another example is microRNA-21 that was first identified as a potential oncogene in glioblastoma and several other solid organ cancers (breast, prostate, stomach, lung) $[19,26,27]$. The function of microRNA-21 as an oncogene was further validated by demonstration of increased apoptotic cell death and decreased growth upon its inhibition in breast and glioblastoma cell lines. These studies support that microRNA-21 promotes tumorigenesis by suppressing apoptosis $[26,27]$.

The first identification of microRNA function in tumour suppression originated with identification of loss of the locus of chromosome 13q14 where microRNA-15a and microRNA-16-1 are clustered in approximately one half of CLL (chronic lymphocytic leukemia) and other cancers such as prostate [28-30]. Finally the demonstration that the RAS oncogene is a target for the human let-7 family members has provided another potential role of microRNA genes as tumour suppressor genes $[\underline{8}, \underline{31}]$. The low expression of let- 7 has been correlated with high expression of RAS in lung cancers, providing a mechanism by which microRNA function loss can be a promoter of tumorigenesis [32].

Several microRNAs were found to have specific alterations in oral cavity squamous cell carcinomas. Among these, several microRNAs have been functionally validated and their potential target genes have been identified. Some microRNAs have direct targets while others have indirect effect or target several genes.

\section{Oral cancer related MicroRNAs potential target genes - direct interactions}

MicroRNA-184 was identified to be among the 24 up-regulated mature microRNAs by at least 3 -fold expression difference in laser microdissected cells from four tongue squamous cell carcinomas and paired normal controlled. The cellular response to microRNA-184 inhibition, demonstrated smaller and denser cells compared to control cultures. Proliferation assays showed reduced proliferation after transfection with microRNa-184 inhibitor compared with controls. In two of the cell lines (Cal27 and HN96) immunostaining for c-Myc showed that the c-Myc positive cells were decreased after transfection (34\% versus $76 \%$ in Cal27 and $32 \%$ versus $78 \%$ in HN96). Furthermore in the transfected cell lines there was statistically significant difference in the percentage of apoptotic cells compared to the controls: Cal27: $10.64 \%$ versus $0.35 \%, \mathrm{HN} 21 \mathrm{~B}$ : $7.05 \%$ versus $0.62 \%$ and HN96: $9.25 \%$ versus $0.78 \%$ (all $\mathrm{P}<0.05$, using Mann-Whitney U test). It was thus postulated that microRNA-184 acts as an oncogene by 
inducing proliferation and inhibiting apoptosis potentially by targeting c-Myc [33]. Another study though has recently proposed a different explanation for the effects of microRNA-184 on epithelial cells and cancer cell lines, including Cal27 (an aggressive behaving cell line) via Akt signaling. Suppression of the Akt pathway that is associated with increased cell apoptosis and death was demonstrated with ectopic expression of microRNA-184 [34]. Additional studies to clarify these contradicting findings are required.

The function of microRNA-137 and microRNA$193 a$ (studied together) as tumour suppressors was demonstrated in oral squamous cell carcinoma cell lines. It has been demonstrated that both microRNAs are silenced by tumour specific DNA hypermethylation using these cell lines. MicroRNA-137 when ectopically expressed in cell lines lacking its expression inhibited growth via Go-G1 arrest. MicroRNA-193a in contrast demonstrated same results by caspase-mediated apoptosis. After testing the potential targets based on computer predictions [(CDK6, E2F6, NCOA2/TIF2 for microRNA-137) and (E2F6, KRAS, MCL1, MYCN, PTK2/FAK for microRNA-193a)] the only statistically significant differences in protein levels and control transfectans revealed CDK6 as potential target for microRNA-137 and E2F6 for microRNA-193a [35]. Interestingly in a recent study microRNA-137 was found to induce cell cycle arrest at G1, inhibit invasion and target cell division cycle $42(\mathrm{Cdc} 42)$ one of the best characterized members of the Rho GTPase family in colorectal cancer cells. Cdc42 has been shown to be up-regulated in several human cancers including head and neck. Consideration should be given to investigate Cdc42 as a target for microRNA-137 in oral cancers $[\underline{36}, \underline{37}]$.

In the study by Wong et al. using laser-captured microdissected tissue from squamous cell carcinoma of the oral tongue microRNA-133a and microRNA-133b were identified to be derregulated compared to paired normal epithelial cells [33]. Reduction of proliferation rate and increase in apoptotic cells were noted when the cells from the tongue SCC cell line Cal27 were transfected. Computer target gene prediction proposed that pyruvate kinase type M2 (PKM2) transcription could be targeted by both microRNA-133a and microRNA-133b. In tumorigenesis replacement of the tissue specific PKM by PKM2 occurs and is believed to facilitate adaptation of cells to potentially low glucose and oxygen environment and facilitate tumour invasion. Up-regulation of PKM2 has been demonstrated in several tumours including colorectal, skin and gastric cancers [38-40].

The ability of tumour cells to adapt to microenvironment alterations is a key element for their survival and tumour progression. Ability to survive under hypoxia conditions or in the presence of chemotherapeutic agents by developing resistance is major contributor to treatment failures and yet still poorly understood. Studies have shown that there is some contribution from microRNA deregulation to these adaptations by cancer cells as mentioned earlier. Partial regulation of the High Mobility Group A2 (HMGA2) protein, a member of the HMGA family, was identified to be controlled at least in part by miRNA-98 in cancer cell lines from the head and neck studied in hypoxia conditions. HMGA2 expression occurs predominately during embryogenesis. However, proteins from the HMGA family are implicated in differentiation, neoplastic transformation, integration and expression of viral genome. Studies of HMGA2 in breast cancer have shown association of increased expression with poor prognosis and metastasis. In oral squamous cell carcinoma the same protein has been implicated in acquisition of mesenchymal characteristics by the epithelial cells. MicroRNAs from the let-7 family were also found to contribute to changes of the protein expression during these hypoxia conditions [41-43].

\section{Oral Cancer related MicroRNAs potential target genes - complex interactions}

Cohen et al. demonstrated a DNA synthesis control involving microRNA-15a that affects cell cycle progression using a human tumour xenograft [44]. The xenoglaft involved injection of SQ20B tumour cells into limbs of female athymic nude mice. Protein kinase $\mathrm{C}$ alpha (PKCa) was identified as a key mediator of squamous cell carcinoma proliferation via activation of MAPK and negative regulation of microRNA-15a that inhibits cyclin E expression. These interactions lead to increased cell cycle proteins and thus enhanced DNA synthesis. In brief MAPK is shown to be required for DNA synthesis in SQ20B cells and activation initiates cell proliferation while growth is maintained via additional mechanisms. Cyclin E deregulation on the other hand has been associated with a number of highly aggressive tumours and poor prognosis, such as in laryngeal squamous cell carcinoma. Finally microRNA-15a is a DNA synthesis inhibitor. This feed forward loop involves protein kinase $\mathrm{Ca}$ that inhibits micraRNA $15 a$ that allows uninhibited cyclin E expression and thus promotes DNA synthesis [44-47].

Perhaps the most consistently deregulated microRNA that has been identified in malignant processes is microRNA-21. It is a well established oncogene that has been demonstrated to promote cell proliferation and suppresses apoptosis identified in various cancers 
including squamous cell carcinoma of the head and neck/oral cavity. Once it was realized that microRNA-21 transfected cells had a growth advantage over normal controls the potential targets were investigated. Several potential target genes have been suggested over the years. Zhu et al. demonstrated that microRNA-21 function as oncogene and its role in tumorigenesis is at least in part through regulation of the tumour suppressor gene tropomyosin 1 (TPM1) [48]. Two additional direct targets were identified in the same study: programmed cell death 4 (PDCD4) and maspin. Both these genes are implicated in cell invasion and tumour metastasis in breast cancers. It was soon realized that the actual role of microRNA-21 in tumorigenesis is accomplished by complex interactions with tumour/metastasis and suppressor genes [48]. A capsase activation that occurs with knockdown of microRNA-21, proposed by Chang et al., triggered the investigation of the potential role of microRNA-21 in the apoptotic pathway in head and neck cancers [49]. This was accomplished by studying the release of cytochrome $\mathrm{c}$ since it precedes activation of capsase. Inhibition of microRNA-21 caused decrease in cytochrome c release that taken together with the findings from transfection data suggests that the downstream targets of microRNA-21 are unlikely to be any of the major suppressor genes. The authors speculated that it would be more realistic that microRNA-21 inhibits several mRNAs and thus a cascade of events, that prevents apoptosis and thus increase in proliferation is initiated $[\underline{26}, \underline{49}]$.

Using samples from tongue specimens and normal controls $\mathrm{Li}$ et al. were able to demonstrate a reverse correlation between two tumour suppressor genes and microRNA-21 [무]. Both TPM1 and PTEN (phosphatase tensin homologue) genes' expression was inhibited by microRNA-21 in oral tongue cancers. TPM1 and PTEN immunohistochemistry staining was significantly different between cancer and adjacent normal tissues as well. Inhibition of microRNA-21 in tongue cancer cell lines reduced survival and anchorage dependant growth and induced apoptosis. Lastly, microRNA-21 was found to be an independent prognosticator of poor survival for tongue squamous cell carcinoma [50-52].

Ten oral squamous cell carcinoma (OSCC) cell lines and NHOK controls were used to study microRNA$125 \mathrm{~b}$ and microRNA-100. Levels for both microRNAs were lower in OSCC cell lines than controls. Among the potential target genes altered by each microRNA, seven were studied further. KLF13, CXCL11, FOAX1 for microRNA-125b and LD1, EGR2, MMP13 and EGFR2 for microRNA-100. Transfection of OSCC cell lines with microRNA-125b resulted in the following interesting observations: KLF13 was down-regulated, CXCL11 and FOXA1 were upregulated. Cell proliferation, along with modification of gene expression, is some important biological functions controlled by microRNA-125. KLF13 for example is a transcription factor and is involved in cell proliferation and differentiation of the heart in addition to development of B-cell and T-cell. Another interesting observation is that KLF13 is required for expression of cyclin D1 (and CCL5) that is known to be over expressed in human OSCC $[\underline{53}, \underline{54}]$. CXL11 is a chemokine and a prominent ligant for CXCR3 that is involved in immunity, inflammation, and angiostasis and has been implicated in several cancers $[\underline{55}, \underline{56}]$. In an animal model CXCL11 increased survival and reduced metastasis [57]. FOXA1 a transcription factor has been shown to be involved in both events: growth stimulation and repression, while is responsible for expression of estrogen responsive genes. In prostate cancer FOXA1 over expression blocks metastasis and inhibits proliferation [58-60]. These observations may have therapeutic implications taking into consideration the function of the target genes altered by microRNA-125b.

MicroRNA-100 is down-regulated in head and neck cancers among others and transfection of OSCC lines modified the expression of several genes. EGFR3, a fibroblast growth factor receptor and predicted target for microRNA-100, is mutated in several malignancies including oral squamous cell carcinoma and is involved in development and proliferation [61]. ID1 a helixloop-helix protein that inhibits transcription is over expressed in a variety of malignancies, including oral and esophageal squamous cell carcinoma and has been associated with metastasis in breast cancers [2-65]. MMP13, a member of the matrix metalloproteinase family of proteins, is responsible for activation of other MMP members and is altered in OSCC cells transfected with microRNA-100 and so is EGFR2 a transcription factor that is over-expressed in oral squamous cell carcinoma [66-70]. Both microRNA$125 \mathrm{~b}$ and microRNA-100 have the ability to modify the expression of non target genes supporting their role of contribution to oral cancer via direct and indirect mechanisms.

Up-regulation of microRNA-24 has been observed in a number of cancers including OSCC $[\underline{19}, \underline{71}, \underline{72}]$. In OSCC, specifically up-regulation of microRNA-24 appears to be associated with disease progression. The study by Liu et al. in 2010 using tissue samples and adjacent normal tissue confirmed the up-regulation of microRNA-24 in tongue squamous cell carcinoma, one of the most common subtypes of oral cancer [73]. It was further demonstrated that microRNA-24 expresses its 
effects in part through targeting RNA-binding protein DND1, which in turn post-transcriptionally regulates its downstream genes, including cyclin-dependent kinase inhibitor 1B (CDKN1B). It has been shown previously that the expression of cyclin-dependant kinase inhibitor 1B (CDKN1B) is up-regulated by DND1 at the post-transcriptional level [74].

Among the several important candidate targets for microRNa-24 predicted DND1 was of interest as DND1 has been shown to modulate microRNA activity by binding to the microRNA targeting sequences on the $3^{0}$ UTR of the targeted mRNAs [74]. Therefore, DND1 post-transcriptionally regulates gene expression by inhibiting the microRNA access to the target mRNA. Previous studies demonstrated that DND1 is essential for the motility and survival of germ cells in zebrafish, and disruption of DND1 gene can induce testicular germ cell tumours in mice $[\underline{75}, \underline{76}]$.

The group concluded that microRNA-24 is a multifunctional molecule regulator that regulates a variety of biological processes. One of its major roles in tongue cancer is regulating cell proliferation and apoptosis by targeting inhibitors of cyclin-dependent kinases (e.g., CDKN1B and CDKN2A). Furthermore, the results from the study suggested an intriguing mechanism for microRNA-24 to express its effects through targeting DND1, which in turn regulates a group of downstream genes at post-transcriptional levels [76].

MicroRNA-7 has been demonstrated to function as tumour suppresser in several cancers and was found to be down-regulated in oral tongue cancer cell lines

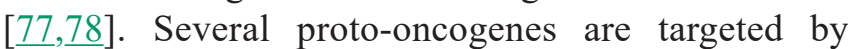
microRNA-7 including insulin receptor substrate 1 (IRS1), insulin receptor substrate 2 (IRS2) epidermoid growth factor receptor (EGFR), v-raf-1 murine leukemia viral oncogene homolog 1 (RAF1) and p21/ CDC42/RAC1-activated kinase 1 (PAK1) [79-81]. MicroRNA-7 was initially studied by Liu et al. in 2009 in two oral cancer cell lines (UM1 and UM2) derived from the same patient that demonstrated though differences in aggressiveness [78]. The group demonstrated that UM1, the more aggressively behaving cell line, exhibited reduced microRNA-7 levels when compared to the less aggressive line UM2. Subsequent studies by Jiang et al. in 2010 using the same cell lines determined that insulin-like growth factor 1 receptor (IGF1R) is a target of microRNA-7 in oral tongue squamous cell carcinoma cell lines [82]. It was further shown that down-regulation of IGF1R that in turn attenuated the insulin growth factor 1 (IGF1) induced activation of protein kinase $\mathrm{B}$ was mediated by microRNA-7. The activation of protein kinase $B$ leads to reduced cell proliferation and cell cycle arrest and an increased apoptosis rate. The function of
microRNA-7 on several key signaling molecules in several human cancers, including oral tongue cancer based on the findings from this study, indicates a contribution to carcinogenesis via multiple pathways and in various levels [르].

Dihydrofolate reductase (DHFR) gene was found to be a target for microRNA-205 which was consistently down-regulated in squamous cell carcinoma of the head and neck including the oral tongue compared to adjacent normal tissue. DHFR plays a critical role in folate metabolism and represents a target of methetraxate, a commonly used chemotherapy agent. DHFR activity is associated with the tumour suppressor gene p53 as both are targeted for degradation through the MDM2 ubiquitin ligase pathway. A specific MDM2 polymorphism, SNP309, has been correlated with poor prognosis in some cancers and early in head and neck cancer [83]. An additional link to these two pathways is through $\mathrm{p} 14^{\mathrm{ARF}}$ that is frequently lost or mutated in these cancers. P14 ${ }^{\mathrm{ARF}}$ activity results in increased degradation of DHFR that in turn results in resistance to folate antagonists such as methotrexate, in cell that have non functional, mutated p53 [84].

Two putative genes for microRNA-138 precursors, termed pre-microRNA-138-1 and premicroRNA-138-2, have been predicted in mouse genome recently [85]. Their human homologs have been located on chromosome $3 \mathrm{p} 21.33$ and $16 \mathrm{q} 13$, respectively. Interestingly, loss of heterozygosity $(\mathrm{LOH})$ at both chromosome loci has been frequently detected in HNSCC and appears to correlate with tumour progression (i.e., cervical lymph node metastasis) [86-88]. The study demonstrated that reduced microRNA-138 level is associated with enhanced metastatic potential in OSCC. The molecular mechanism(s) that underlie the effect of microRNA-138 on metastasis were further investigated by Jiang et al. in 2010 using bioinformatics-based prediction [89]. A total of 86 potential targets for microRNA-138 were identified [89]. Among those predicted targets, 3 of them are major players in the Rho GTPase signaling cascade. These targets are as follows: RhoC, 1 of the 3 Rho GTPases; ROCK2, a Rho-associated kinase and ARHGEF3, one of the guanine nucleotide exchange factors (GEFs). The Rho GTPase is a subfamily of the Ras superfamily. The members of the Rho GTPase family have been described as "molecular switches" that regulate cell shape, polarity and locomotion through their effects on many aspects of intracellular actin dynamics [90]. There are 3 Rho GTPases in human, RhoA, RhoB and $\mathrm{RhoC}$, which share $85 \%$ amino acid sequence identity and exhibit distinct cellular functions [91]. RhoA plays key roles in the regulation of 
actomyosin contractility as well as cell proliferation and survival. RhoB, which is localized primarily on endosomes, has been shown to regulate cytokine trafficking and cell survival. RhoC plays a major role in the regulation of actin cytoskeleton, cell shape, attachment and motility, which is highly relevant to cancer metastasis. Rho GTPases carry out these distinct functions by activating various downstream effectors, including Rho-associated kinases (such as ROCK1 and ROCK2). The activity of Rho GTPases is tightly controlled by several families of regulators, including guanine nucleotide dissociation inhibitors, GEFs and GTPase-activating proteins. These constitute the major players in the Rho GTPase signaling pathway [91]. Based on the bioinformatic analysis as well as the observed cellular changes associated with microRNA-138 noted by Liu et al. the group hypothesized that microRNA-138 regulates the cancer metastasis by targeting the Rho GTPase signaling cascade [77,78]. These findings were in agreement with previous studies demonstrating that the expression of $\mathrm{RhoC}$ is progressively increased as

Table 1. Commonly deregulated microRNAs in head and neck/oral cavity cancer (HNOCC) and their proposed target genes

\begin{tabular}{|c|c|c|}
\hline $\begin{array}{l}\text { MicroRNAs } \\
\text { deregulated } \\
\text { in HNOCC }\end{array}$ & $\begin{array}{l}\text { Proposed Target gene(s) } \\
\text { additional mechanisms and findings }\end{array}$ & $\begin{array}{c}\text { Author / Year / } \\
\text { Journal }\end{array}$ \\
\hline microRNA-184 & c-Myc & $\begin{array}{l}\text { Wong et al. / } 2008 \text { / Clin. } \\
\text { Cancer Research. }\end{array}$ \\
\hline $\begin{array}{l}\text { micrRNA-133a } \\
\quad \text { and } \\
\text { microRNA-133b }\end{array}$ & $\begin{array}{c}\text { PKM2 } \\
\text { (pyruvate kinase type 2) }\end{array}$ & $\begin{array}{l}\text { Wong et al. / } 2008 \text { / Int. J. } \\
\text { Cancer. }\end{array}$ \\
\hline
\end{tabular}

microRNA-137

and

microRNA-193a

(n)

microRNA-15a

TPM1 and PTEN
(tropomyosin 1 and phosphatase tensin)
microRNA-21 $\begin{aligned} & \text { Most likely actual role of microR } N A-21 \text { in tumorigenesis is accomplished by } \\ & \text { complex interactions with tumour / metastasis and suppressor genes }\end{aligned}$

(cyclin dependant kinase 6)

E2F transcription factor 6

Additionally it was demonstrated that these two microRNAs are tumour suppressors epigenetically silenced during oral carcinogenesis through DNA hypermethylation

\section{Cyclin E}

$\mathrm{PKCa}$ (protien kinase $\mathrm{c}$ alpha) down regulates microRNA-15a that directly inhibits cyclin $\mathrm{E}$
Kozaki et al. / 2008 / Cancer Research.

Cohen et al /2009 / Cancer Research

Zhu et al. / 2007 / Biol. Chem.

Li et al. / 2008 / Clin. Cancer

Research.

Chang et al. / 2008 / J. Dent. Res.

\begin{tabular}{|c|c|c|}
\hline $\begin{array}{l}\text { microRNA-103 } \\
\text { and } \\
\text { microRNA-107 }\end{array}$ & $\begin{array}{c}\text { PDCD4 } \\
\text { (programmed cell death protein 4) } \\
\text { TGFBR3 } \\
\text { (tumour growth factor receptor beta 3) }\end{array}$ & $\begin{array}{l}\text { Ramdas et al. / } 2008 \text { / Head } \\
\text { and Neck. }\end{array}$ \\
\hline $\begin{array}{l}\text { microRNA-205 } \\
\quad \text { and }\end{array}$ & $\begin{array}{l}\text { DHFR } \\
\text { (dihydrofolate reductase) }\end{array}$ & $\begin{array}{l}\text { Nakashima et al. / } 2008 \text { / Acta } \\
\text { Otolar. }\end{array}$ \\
\hline let-7 & $\begin{array}{l}\text { let- } 7 \text { has been associated in oral cancers with decreased survival in cases with the } \\
\text { KRAS-LCS6 genotype variant }\end{array}$ & $\begin{array}{l}\text { Christensen et al. / } 2009 \text { / } \\
\text { Carcinogenesis. }\end{array}$ \\
\hline
\end{tabular}

\begin{tabular}{|c|c|c|}
\hline $\begin{array}{l}\text { microRNA-125b } \\
\quad \text { and } \\
\text { microRNA-100 }\end{array}$ & $\begin{array}{c}\text { KLF13, CXCL11 and FOXA1 } \\
\text { and } \\
\text { EGFR3 } \\
\text { (epidermoid growth factor receptor 3) }\end{array}$ & $\begin{array}{l}\text { Henson et al. / } 2009 \text { / Genes } \\
\text { Chromosomes Cancer. }\end{array}$ \\
\hline microRNA-222 & $\begin{array}{c}\text { MMP1 } \\
\text { (matrix metalloproteinase 1) } \\
\text { SOD2 } \\
\text { (manganese superoxide dismutase 2) }\end{array}$ & $\begin{array}{l}\text { Liu et al / 2009/ Cancer } \\
\text { Genom. Proteom. }\end{array}$ \\
\hline $\operatorname{microRNA-24}$ & $\begin{array}{l}\text { DND1 } \\
\text { (dead end 1, an RNA binding protein which in turn regulates a group of } \\
\text { downstream genes at post-transcriptional levels) }\end{array}$ & Liu et al. / 2009/ FEBS letters. \\
\hline microRNA-7 & $\begin{array}{c}\text { IGF1R } \\
\text { (insulin-like growth factor1 receptor) }\end{array}$ & $\begin{array}{l}\text { Jiang et al. / } 2010 \text { / Biochemical } \\
\text { Journal. }\end{array}$ \\
\hline microRNA-138 & $\begin{array}{c}\text { GNAI2 } \\
\text { (G protein alpha inhibiting activity polypeptide } 2 \text { ) }\end{array}$ & $\begin{array}{l}\text { Jiang et al. / } 2010 / \text { International } \\
\text { J. of Cancer. }\end{array}$ \\
\hline
\end{tabular}




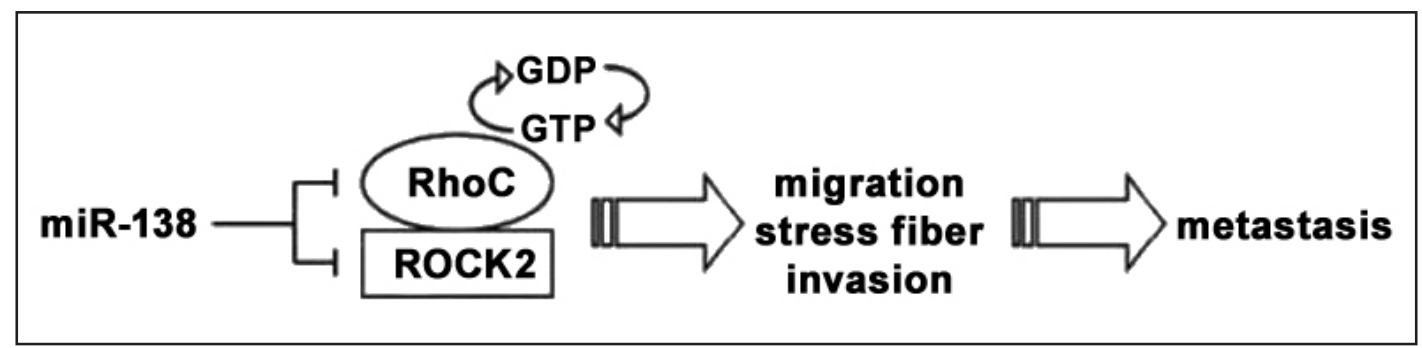

Figure 1. Potential roles of microRNA-138 on RhoCGTPase signalling cascade and cancer cell metastasis. Courtesy of Dr. Xiaofeng Zhou.

tumours become more aggressively metastatic, and that RhoC expression promotes metastasis [92-94]. RhoC functions through direct interaction with its downstream signaling molecule, Rho associated kinases (e.g., ROCK1 and ROCK2), which in turn phosphorylate both a range of cytoskeletal proteins allowing for the generation of contractile forces and the ezrin family proteins that link the actin cytoskeleton to the plasma membrane. ROCK2 was identified as another direct microRNA-138 target gene in the Rho GTPase signaling pathway, and a highly conserved targeting site for microRNA-138 was identified in the $3^{0} \mathrm{UTR}$ of the ROCK $2 \mathrm{mRNA}$. These results suggested that microRNA-138 regulates ROCK2 gene expression primarily by inhibiting translation.

Metastasis requires passage across tissue boundaries, which is facilitated by increased cancer cell motility due to cytoskeletal remodeling. The Rho GTPases signaling cascade plays a central role in regulating cell adhesion, migration and the cytoskeleton [90]. Although Rho family gene mutations are relatively rare in tumours, over-expression of these genes are common events in cancer cells. The over-expression of key genes in Rho GTPases signaling cascade, including RhoC and ROCK2, has been frequently linked to enhanced metastatic potential in various cancer types [95-98]. A novel paradigm in which microRNA-138 regulates RhoC specific GTPase signaling cascade by targeting both RhoC and ROCK 2 mRNAs concurrently and suppresses their expression at posttranscriptional levels was demonstrated in these studies. This provides further evidence that microRNA-138 functions as a metastasis suppressor gene in tongue squamous cell carcinoma and may serve as a novel target for patients with highly metastatic tumours (Figure 1). Table 1 provides the commonly deregulated microRNAs in head and neck/oral cavity cancer (HNOCC) and their proposed target genes for easy reference.

\section{CONCLUSIONS}

Extensive literature exists on microRNA and its role in carcinogenesis, with more evidence on specific roles of these molecules and their involvement in pathways known to be altered in this disease complex process. The expanding knowledge of specific roles of certain microRNA is further contributing to our understanding of the complexity of tumour progression and behaviour. Consideration of this information and incorporation into treatment modalities through targeted therapy could potentially enhance our abilities to improve outcome especially when other established therapies have failed.

\section{ACKNOWLEDGMENTS AND DISCLOSURE STATEMENTS}

The authors have no conflict of interest to declare.

\section{REFERENCES}

1. Croce CM. Oncogenes and cancer. N Engl J Med. 2008 Jan 31;358(5):502-11. Review. [Medline: 18234754] [FREE Full Text] [doi: 10.1056/NEJMra072367]

2. Bunz F. Tumor Suppressor Genes. In: Bunz F, editor. Principles of Cancer Genetics. Springer; 2008. p. 77-123. [doi: 10.1007/978-1-4020-6784-6_3]

3. Adams JM, Cory S. The Bcl-2 apoptotic switch in cancer development and therapy. Oncogene. 2007 Feb 26;26(9):1324-37. Review. [Medline: 17322918] [FREE Full Text] [doi: 10.1038/sj.onc.1210220]

4. Harris H. Genes and isozymes. Proc R Soc Lond B Biol Sci. 1969 Oct 7;174(34):1-31. Review. [Medline: 4390450] [doi: 10.1098/rspb.1969.0078] 
5. Ohta M, Inoue H, Cotticelli MG, Kastury K, Baffa R, Palazzo J, Siprashvili Z, Mori M, McCue P, Druck T, Croce CM, Huebner K. The FHIT gene, spanning the chromosome 3p14.2 fragile site and renal carcinoma-associated $\mathrm{t}(3 ; 8)$ breakpoint, is abnormal in digestive tract cancers. Cell. 1996 Feb 23;84(4):587-97. [Medline: 8598045] [doi: 10.1016/S0092-8674(00)81034-X]

6. Huebner K, Croce CM. FRA3B and other common fragile sites: the weakest links. Nat Rev Cancer. 2001 Dec;1(3):214-21. [Medline: 11902576] [doi: 10.1038/35106058]

7. Calin GA, Liu CG, Sevignani C, Ferracin M, Felli N, Dumitru CD, Shimizu M, Cimmino A, Zupo S, Dono M, Dell'Aquila ML, Alder H, Rassenti L, Kipps TJ, Bullrich F, Negrini M, Croce CM. MicroRNA profiling reveals distinct signatures in B cell chronic lymphocytic leukemias. Proc Natl Acad Sci U S A. 2004 Aug 10;101(32):11755-60. Epub 2004 Jul 29. [Medline: 15284443] [FREE Full Text] [doi: 10.1073/pnas.0404432101]

8. Calin GA, Sevignani C, Dumitru CD, Hyslop T, Noch E, Yendamuri S, Shimizu M, Rattan S, Bullrich F, Negrini M, Croce CM. Human microRNA genes are frequently located at fragile sites and genomic regions involved in cancers. Proc Natl Acad Sci U S A. 2004 Mar 2;101(9):2999-3004. Epub 2004 Feb 18. [Medline: 14973191] [FREE Full Text] [doi: 10.1073/pnas.0307323101]

9. Calin GA, Dumitru CD, Shimizu M, Bichi R, Zupo S, Noch E, Aldler H, Rattan S, Keating M, Rai K, Rassenti L, Kipps T, Negrini M, Bullrich F, Croce CM. Frequent deletions and down-regulation of micro- RNA genes miR15 and miR16 at $13 q 14$ in chronic lymphocytic leukemia. Proc Natl Acad Sci U S A. 2002 Nov 26;99(24):15524-9. Epub 2002 Nov 14. [Medline: 12434020] [FREE Full Text] [doi: 10.1073/pnas.242606799]

10. Liu X, Chen Z, Yu J, Xia J, Zhou X. MicroRNA profiling and head and neck cancer. Comp Funct Genomics. 2009:837514. Epub 2009 Jun 1. [Medline: 19753298] [FREE Full Text]

11. Wiemer EA. The role of microRNAs in cancer: no small matter. Eur J Cancer. 2007 Jul;43(10):1529-44. Epub 2007 May 24. Review. [Medline:17531469] [doi: 10.1016/j.ejca.2007.04.002]

12. Lee YS, Dutta A. MicroRNAs: small but potent oncogenes or tumor suppressors. Curr Opin Investig Drugs. 2006 Jun;7(6):560-4. Review. [Medline: 16452165]

13. Chen PY, Meister G. microRNA-guided posttranscriptional gene regulation. Biol Chem. 2005 Dec;386(12):1205-18. Review. [Medline: 16336116] [doi: 10.1515/BC.2005.139]

14. Chen Y, Gorski DH. Regulation of angiogenesis through a microRNA (miR-130a) that down-regulates antiangiogenic homeobox genes GAX and HOXA5. Blood. 2008 Feb 1;111(3):1217-26. Epub 2007 Oct 23. [Medline: 17957028] [FREE Full Text] [doi: 10.1182/blood-2007-07-104133]

15. Cummins JM, Velculescu VE. Implications of micro-RNA profiling for cancer diagnosis. Oncogene. 2006 Oct 9;25(46):6220-7. Review. [Medline: 17028602] [FREE Full Text] [doi: 10.1038/sj.onc.1209914]

16. Hayashita Y, Osada H, Tatematsu Y, Yamada H, Yanagisawa K, Tomida S, Yatabe Y, Kawahara K, Sekido Y, Takahashi T. A polycistronic microRNA cluster, miR-17-92, is overexpressed in human lung cancers and enhances cell proliferation. Cancer Res. 2005 Nov 1;65(21):9628-32. [Medline: 16266980] [FREE Full Text] [doi: 10.1158/0008-5472.CAN-05-2352]

17. He L, Thomson JM, Hemann MT, Hernando-Monge E, Mu D, Goodson S, Powers S, Cordon-Cardo C, Lowe SW, Hannon GJ, Hammond SM. A microRNA polycistron as a potential human oncogene. Nature. 2005 Jun 9;435(7043):82833. [Medline: 15944707] [doi: 10.1038/nature03552]

18. Ota A, Tagawa H, Karnan S, Tsuzuki S, Karpas A, Kira S, Yoshida Y, Seto M. Identification and characterization of a novel gene, C13orf25, as a target for 13q31-q32 amplification in malignant lymphoma. Cancer Res. 2004 May 1;64(9):3087-95. [Medline: 15126345] [FREE Full Text] [doi: 10.1158/0008-5472.CAN-03-3773]

19. Volinia S, Calin GA, Liu CG, Ambs S, Cimmino A, Petrocca F, Visone R, Iorio M, Roldo C, Ferracin M, Prueitt RL, Yanaihara N, Lanza G, Scarpa A, Vecchione A, Negrini M, Harris CC, Croce CM. A microRNA expression signature of human solid tumors defines cancer gene targets. Proc Natl Acad Sci U S A. 2006 Feb 14;103(7):2257-61. Epub 2006 Feb 3. [Medline: 16461460] [FREE Full Text] [doi: 10.1073/pnas.0510565103]

20. Dews M, Homayouni A, Yu D, Murphy D, Sevignani C, Wentzel E, Furth EE, Lee WM, Enders GH, Mendell JT, Thomas-Tikhonenko A. Augmentation of tumor angiogenesis by a Myc-activated microRNA cluster. Nat Genet. 2006 Sep;38(9):1060-5. Epub 2006 Jul 30. [Medline: 16878133] [FREE Full Text] [doi: 10.1038/ng1855]

21. Fernandez PC, Frank SR, Wang L, Schroeder M, Liu S, Greene J, Cocito A, Amati B. Genomic targets of the human c-Myc protein. Genes Dev. 2003 May 1;17(9):1115-29. Epub 2003 Apr 14. [Medline: 12695333] [FREE Full Text] [doi: $10.1101 / \mathrm{gad} .1067003$ ]

22. Li Z, Van Calcar S, Qu C, Cavenee WK, Zhang MQ, Ren B. A global transcriptional regulatory role for c-Myc in Burkitt's lymphoma cells. Proc Natl Acad Sci U S A. 2003 Jul 8;100(14):8164-9. Epub 2003 Jun 13. [Medline: 12808131] [FREE Full Text] [doi: 10.1073/pnas.1332764100]

23. Orian A, van Steensel B, Delrow J, Bussemaker HJ, Li L, Sawado T, Williams E, Loo LW, Cowley SM, Yost C, Pierce S, Edgar BA, Parkhurst SM, Eisenman RN. Genomic binding by the Drosophila Myc, Max, Mad/Mnt transcription factor network. Genes Dev. 2003 May 1;17(9):1101-14. Epub 2003 Apr 14. [Medline: 12695332] [FREE Full Text] [doi: $10.1101 / \mathrm{gad} .1066903$ ] 
24. O’Donnell KA, Wentzel EA, Zeller KI, Dang CV, Mendell JT. c-Myc-regulated microRNAs modulate E2F1 expression. Nature. 2005 Jun 9;435(7043):839-43. [Medline: 15944709] [doi: 10.1038/nature03677]

25. Levens D. Disentangling the MYC web. Proc Natl Acad Sci U S A. 2002 Apr 30;99(9):5757-9. Review. [Medline: 11983876] [FREE Full Text] [doi: 10.1073/pnas.102173199]

26. Chan JA, Krichevsky AM, Kosik KS. MicroRNA-21 is an antiapoptotic factor in human lioblastoma cells. Cancer Res. 2005 Jul 15;65(14):6029-33. [Medline: 16024602] [FREE Full Text] [doi: 10.1158/0008-5472.CAN-05-0137]

27. Si ML, Zhu S, Wu H, Lu Z, Wu F, Mo YY. miR-21-mediated tumor growth. Oncogene. 2007 Apr 26;26(19):2799-803. Epub 2006 Oct 30. [Medline: 17072344] [doi: 10.1038/sj.onc.1210083]

28. Döhner H, Stilgenbauer S, Benner A, Leupolt E, Kröber A, Bullinger L, Döhner K, Bentz M, Lichter P. Genomic aberrations and survival in chronic lymphocytic leukemia. N Engl J Med. 2000 Dec 28;343(26):1910-6. [Medline: 11136261] [FREE Full Text] [doi: 10.1056/NEJM200012283432602]

29. Dong JT, Boyd JC, Frierson HF Jr. Loss of heterozygosity at 13q14 and 13q21 in high grade, high stage prostate cancer. Prostate. 2001 Nov 1;49(3):166-71. [Medline: 11746261] [doi: 10.1002/pros.1131]

30. Cimmino A, Calin GA, Fabbri M, Iorio MV, Ferracin M, Shimizu M, Wojcik SE, Aqeilan RI, Zupo S, Dono M, Rassenti L, Alder H, Volinia S, Liu CG, Kipps TJ, Negrini M, Croce CM. miR-15 and miR-16 induce apoptosis by targeting BCL2. Proc Natl Acad Sci U S A. 2005 Sep 27;102(39):13944-9. Epub 2005 Sep 15. Erratum in: Proc Natl Acad Sci U S A. 2006 Feb 14;103(7):2464. [Medline: 16166262] [FREE Full Text] [doi: 10.1073/pnas.0506654102]

31. Takamizawa J, Konishi H, Yanagisawa K, Tomida S, Osada H, Endoh H, Harano T, Yatabe Y, Nagino M, Nimura Y, Mitsudomi T, Takahashi T. Reduced expression of the let-7 microRNAs in human lung cancers in association with shortened postoperative survival. Cancer Res. 2004 Jun 1;64(11):3753-6. [Medline: 15172979] [FREE Full Text] [doi: 10.1158/0008-5472.CAN-04-0637]

32. Chang TC, Mendell JT. microRNAs in vertebrate physiology and human disease. Annu Rev Genomics Hum Genet. 2007;8:215-39. Review. [Medline: 17506656] [doi: 10.1146/annurev.genom.8.080706.092351]

33. Wong TS, Liu XB, Wong BY, Ng RW, Yuen AP, Wei WI. Mature miR-184 as Potential Oncogenic microRNA of Squamous Cell Carcinoma of Tongue. Clin Cancer Res. 2008 May 1;14(9):2588-92. [Medline: 18451220] [ㅌREE Full Text] [doi: 10.1158/1078-0432.CCR-07-0666]

34. Yu J, Ryan DG, Getsios S, Oliveira-Fernandes M, Fatima A, Lavker RM. MicroRNA-184 antagonizes microRNA-205 to maintain SHIP2 levels in epithelia. Proc Natl Acad Sci U S A. 2008 Dec 9;105(49):19300-5. Epub 2008 Nov 25. [Medline: 19033458] [FREE Full Text] [doi: 10.1073/pnas.0803992105]

35. Kozaki K, Imoto I, Mogi S, Omura K, Inazawa J. Exploration of tumor-suppressive microRNAs silenced by DNA hypermethylation in oral cancer. Cancer Res. 2008 Apr 1;68(7):2094-105. [Medline: 18381414] [FREE Full Text] [doi: 10.1158/0008-5472.CAN-07-5194]

36. Liu M, Lang N, Qiu M, Xu F, Li Q, Tang Q, Chen J, Chen X, Zhang S, Liu Z, Zhou J, Zhu Y, Deng Y, Zheng Y, Bi F. miR137 targets Cdc42 expression, induces cell cycle G1 arrest and inhibits invasion in colorectal cancer cells. Int J Cancer. 2011 Mar 15;128(6):1269-79. [Medline: 20473940] [doi: 10.1002/ijc.25452]

37. Abraham MT, Kuriakose MA, Sacks PG, Yee H, Chiriboga L, Bearer EL, Delacure MD. Motility-related proteins as markers for head and neck squamous cell cancer. Laryngoscope. 2001 Jul;111(7):1285-9. [Medline: 11568556] [doi: 10.1097/00005537-200107000-00027]

38. Kaura B, Bagga R, Patel FD. Evaluation of the Pyruvate Kinase isoenzyme tumor (Tu M2-PK) as a tumor marker for cervical carcinoma. J Obstet Gynaecol Res. 2004 Jun;30(3):193-6. [Medline: 15210041] [doi: 10.1111/j.1447-0756.2004.00187.x]

39. Ugurel S, Bell N, Sucker A, Zimpfer A, Rittgen W, Schadendorf D. Tumor type M2 pyruvate kinase (TuM2PK) as a novel plasma tumor marker in melanoma. Int J Cancer. 2005 Dec 10;117(5):825-30. [Medline: 15957165] [doi: $10.1002 /$ ijc. 21073]

40. Zhang B, Chen JY, Chen DD, Wang GB, Shen P. Tumor type M2 pyruvate kinase expression in gastric cancer, colorectal cancer and controls. World J Gastroenterol. 2004 Jun 1;10(11):1643-6. [Medline: 15162541] [FREE Full Text]

41. Hebert C, Norris K, Scheper MA, Nikitakis N, Sauk JJ. High mobility group A2 is a target for miRNA-98 in head and neck squamous cell carcinoma. Mol Cancer. 2007 Jan 14;6:5. [Medline: 17222355] [FREE Full Text] [doi: $10.1186 / 1476-4598-6-5]$

42. Rogalla P, Drechsler K, Frey G, Hennig Y, Helmke B, Bonk U, Bullerdiek J.HMGI-C expression patterns in human tissues. Implications for the genesis of frequent mesenchymal tumors. Am J Pathol. 1996 Sep;149(3):775-9. [Medline: $\underline{\text { 8780382] }}$ [FREE Full Text]

43. Wikman H, Kettunen E, Seppänen JK, Karjalainen A, Hollmén J, Anttila S, Knuutila S. Identification of differentially expressed genes in pulmonary adenocarcinoma by using cDNA array. Oncogene. 2002 Aug 22;21(37):5804-13. [Medline: 12173052] [FREE Full Text] [doi: 10.1038/sj.onc.1205726]

44. Cohen EE, Zhu H, Lingen MW, Martin LE, Kuo WL, Choi EA, Kocherginsky M, Parker JS, Chung CH, Rosner MR. A feed-forward loop involving protein kinase Calpha and microRNAs regulates tumor cell cycle. Cancer Res. 2009 Jan 1;69(1):65-74. [Medline: 19117988] [FREE Full Text] [doi: 10.1158/0008-5472.CAN-08-0377] 
45. Hwang HC, Clurman BE. Cyclin E in normal and neoplastic cell cycles. Oncogene. 2005 Apr 18;24(17):2776-86. Review. [Medline: 15838514] [FREE Full Text] [doi: 10.1038/sj.onc.1208613]

46. Anton RC, Coffey DM, Gondo MM, Stephenson MA, Brown RW, Cagle PT. The expression of cyclins D1 and E in predicting short-term survival in squamous cell carcinoma of the lung. Mod Pathol. 2000 Nov;13(11):1167-72. [Medline: 11106072] [FREE Full Text] [doi: 10.1038/modpathol.3880215]

47. Dong Y, Sui L, Tai Y, Sugimoto K, Hirao T, Tokuda M. Prognostic significance of cyclin E overexpression in laryngeal squamous cell carcinomas. Clin Cancer Res. 2000 Nov;6(11):4253-8. [Medline: 11106240] [FREE Full Text]

48. Zhu S, Wu H, Wu F, Nie D, Sheng S, Mo YY. MicroRNA-21 targets tumor suppressor genes in invasion and metastasis. Cell Res. 2008 Mar;18(3):350-9. [Medline: 18270520] [FREE Full Text] [doi: 10.1038/cr.2008.24]

49. Chang SS, Jiang WW, Smith I, Poeta LM, Begum S, Glazer C, Shan S, Westra W, Sidransky D, Califano JA. MicroRNA alterations in head and neck squamous cell carcinoma. Int J Cancer. 2008 Dec 15;123(12):2791-7. [Medline18798260] [doi: 10.1002/ijc.23831]

50. Li J, Huang H, Sun L, Yang M, Pan C, Chen W, Wu D, Lin Z, Zeng C, Yao Y, Zhang P, Song E. MiR-21 indicates poor prognosis in tongue squamous cell carcinomas as an apoptosis inhibitor. Clin Cancer Res. 2009 Jun 15;15(12):3998-4008. Epub 2009 Jun 9. [Medline: 19509158] [FREE Full Text] [doi: 10.1158/1078-0432.CCR-08-3053]

51. Meng F, Henson R, Wehbe-Janek H, Ghoshal K, Jacob ST, Patel T. MicroRNA-21 regulates expression of the PTEN tumor suppressor gene in human hepatocellular cancer. Gastroenterology. 2007 Aug;133(2):647-58. Epub 2007 May 21. [Medline: 17681183] [doi: 10.1053/j.gastro.2007.05.022]

52. Zhu S, Si ML, Wu H, Mo YY. MicroRNA-21 targets the tumor suppressor gene tropomyosin 1 (TPM1). J Biol Chem. 2007 May 11;282(19):14328-36. Epub 2007 Mar 15. [Medline: 17363372] [FREE Full Text] [doi: 10.1074/jbc.M611393200]

53. Izzo JG, Papadimitrakopoulou VA, Li XQ, Ibarguen H, Lee JS, Ro JY, El-Naggar A, Hong WK, Hittelman WN. Dysregulated cyclin D1 expression early in head and neck tumorigenesis: in vivo evidence for an association with subsequent gene amplification. Oncogene. 1998 Nov 5;17(18):2313-22. [Medline: 9811462] [FREE Full Text] [doi: 10.1038/sj.onc.1202153]

54. Nemer M, Horb ME. The KLF family of transcriptional regulators in cardiomyocyte proliferation and differentiation. Cell Cycle. 2007 Jan 15;6(2):117-21. Epub 2007 Jan 13. Review. [Medline: 17245133] [FREE Full Text] [doi: $10.4161 /$ cc.6.2.3718]

55. Hensbergen PJ, Wijnands PG, Schreurs MW, Scheper RJ, Willemze R, Tensen CP. The CXCR3 targeting chemokine CXCL11 has potent antitumor activity in vivo involving attraction of CD8+ Tlymphocytes but not inhibition of angiogenesis. J Immunother. 2005 Jul-Aug;28(4):343-51. [Medline: 16000952] [doi: 10.1097/01.cji.0000165355.26795.27]

56. Berencsi K, Meropol NJ, Hoffman JP, Sigurdson E, Giles L, Rani P, Somasundaram R, Zhang T, Kalabis J, Caputo L, Furth E, Swoboda R, Marincola F, Herlyn D. Colon carcinoma cells induce CXCL11-dependent migration of CXCR3expressing cytotoxic T lymphocytes in organotypic culture. Cancer Immunol Immunother. 2007 Mar;56(3):359-70. Epub 2006 Jun 17. [Medline: 16783574] [doi: 10.1007/s00262-006-0190-2]

57. Chu LL, Dou J, Zhao FS, Tang Q, Zhang AF, Wang YF, Gu N. [Anti-tumor mechanisms of Sp2/0 tumor vaccine transfected with mIL-21 gene in mice]. Xi Bao Yu Fen Zi Mian Yi Xue Za Zhi. 2007 Jun;23(6):507-10. Chinese. [Medline: 17553344]

58. Carroll JS, Liu XS, Brodsky AS, Li W, Meyer CA, Szary AJ, Eeckhoute J, Shao W, Hestermann EV, Geistlinger TR, Fox EA, Silver PA, Brown M. Chromosome-wide mapping of estrogen receptor binding reveals long-range regulation requiring the forkhead protein FoxA1. Cell. 2005 Jul 15;122(1):33-43. [Medline: 16009131] [doi: 10.1016/j.cell.2005.05.008]

59. Williamson EA, Wolf I, O'Kelly J, Bose S, Tanosaki S, Koeffler HP. BRCA1 and FOXA1 proteins coregulate the expression of the cell cycle-dependent kinase inhibitor p27(Kip1). Oncogene. 2006 Mar 2;25(9):1391-9. [Medline: 16331276] [FREE Full Text] [doi: 10.1038/sj.onc.1209170]

60. Laganière J, Deblois G, Lefebvre C, Bataille AR, Robert F, Giguère V. From the Cover: Location analysis of estrogen receptor alpha target promoters reveals that FOXA1 defines a domain of the estrogen response. Proc Natl Acad Sci U S A. 2005 Aug 16;102(33):11651-6. Epub 2005 Aug 8. [Medline: 16087863] [FREE Full Text] [doi: 10.1073/pnas.0505575102]

61. Gómez-Román JJ, Saenz P, Molina M, Cuevas González J, Escuredo K, Santa Cruz S, Junquera C, Simón L, Martínez A, Gutiérrez Baños JL, López-Brea M, Esparza C, Val-Bernal JF. Fibroblast growth factor receptor 3 is overexpressed in urinary tract carcinomas and modulates the neoplastic cell growth. Clin Cancer Res. 2005 Jan 15;11(2 Pt 1):459-65. Erratum in: Clin Cancer Res. 2005 Apr 15;11(8):3149. Molina, Miguel [added]. [Medline: 15701828] [FREE Full Text]

62. Perk J, Iavarone A, Benezra R. Id family of helix-loop-helix proteins in cancer. Nat Rev Cancer. 2005 Aug;5(8):603-14. Erratum in: Nat Rev Cancer. 2005 Sep;5(9):750. [Medline: 16034366] [doi: 10.1038/nrc1673]

63. Nishimine M, Nakamura M, Mishima K, Kishi M, Kirita T, Sugimura M, Konishi N. Id proteins are overexpressed in human oral squamous cell carcinomas. J Oral Pathol Med. 2003 Jul;32(6):350-7. [Medline: 12787042] [doi: 10.1034/j.1600-0714.2003.00078.x]

64. Ishigami T, Uzawa K, Higo M, Nomura H, Saito K, Kato Y, Nakashima D, Shiiba M, Bukawa H, Yokoe H, Kawata T, Ito $\mathrm{H}$, Tanzawa $\mathrm{H}$. Genes and molecular pathways related to radioresistance of oral squamous cell carcinoma cells. Int J Cancer. 2007 May 15;120(10):2262-70. [Medline: 17290400] [doi: 10.1002/ijc.22561]

65. Yuen HF, Chan YP, Chan KK, Chu YY, Wong ML, Law SY, Srivastava G, Wong YC, Wang X, Chan KW. Id-1 and Id-2 are markers for metastasis and prognosis in oesophageal squamous cell carcinoma. Br J Cancer. 2007 Nov 19;97(10):140915. Epub 2007 Nov 13. [Medline: 18000500] [FREE Full Text] [doi: 10.1038/sj.bjc.6604035] 
66. Vairaktaris E, Yapijakis C, Nkenke E, Serefoglou ZC, Chatzitheofylaktou A, Vassiliou S, Derka S, Vylliotis A, Perrea D, Neukam FW, Patsouris E. A metalloproteinase-13 polymorphism affecting its gene expression is associated with advanced stages of oral cancer. Anticancer Res. 2007 Nov-Dec;27(6B):4027-30. [Medline: 18225566] [ [FREE Full Text]

67. Leeman MF, McKay JA, Murray GI. Matrix metalloproteinase 13 activity is associated with poor prognosis in colorectal cancer. J Clin Pathol. 2002 Oct;55(10):758-62. [Medline: 12354802] [FREE Full Text] [doi: 10.1136/jep.55.10.758]

68. Chiang WC, Wong YK, Lin SC, Chang KW, Liu CJ. Increase of MMP-13 expression in multi-stage oral carcinogenesis and epigallocatechin-3-gallate suppress MMP-13 expression. Oral Dis. 2006 Jan;12(1):27-33. [Medline: 16390465] [doi: 10.1111/j.1601-0825.2005.01151.x]

69. Liu B, Bernard B, Wu JH. Impact of EGFR point mutations on the sensitivity to gefitinib: insights from comparative structural analyses and molecular dynamicssimulations. Proteins. 2006 Nov 1;65(2):331-46. [Medline: 16927343] [doi: 10.1002/prot.21111]

70. Liu ZM, Huang HS. As2O3-induced c-Src/EGFR/ERK signaling is via Sp1 binding sites to stimulate p21WAF1/CIP1 expression in human epidermoid carcinoma A431 cells. Cell Signal. 2006 Feb;18(2):244-55. [Medline: 15961274] [doi: 10.1016/j.cellsig.2005.04.006]

71. Wang X, Tang S, Le SY, Lu R, Rader JS, Meyers C, Zheng ZM. Aberrant expression of oncogenic and tumor-suppressive microRNAs in cervical cancer is required for cancer cell growth. PLoS One. 2008 Jul 2;3(7):e2557. [Medline: 18596939] [FREE Full Text] [doi: 10.1371/journal.pone.0002557]

72. Lin SC, Liu CJ, Lin JA, Chiang WF, Hung PS, Chang KW. miR-24 up-regulation in oral carcinoma: positive association from clinical and in vitro analysis. Oral Oncol. 2010 Mar;46(3):204-8. Epub 2010 Feb 6. [Medline: 20138800] [doi: 10.1016/j.oraloncology.2009.12.005]

73. Liu X, Wang A, Heidbreder CE, Jiang L, Yu J, Kolokythas A, Huang L, Dai Y, Zhou X. MicroRNA-24 targeting RNAbinding protein DND1 in tongue squamous cell carcinoma. FEBS Lett. 2010 Sep 24;584(18):4115-20. Epub 2010 Sep 4. [Medline: 20816961] [doi: 10.1016/i.febslet.2010.08.040]

74. Kedde M, Strasser MJ, Boldajipour B, Oude Vrielink JA, Slanchev K, le Sage C, Nagel R, Voorhoeve PM, van Duijse J, Ørom UA, Lund AH, Perrakis A, Raz E, Agami R. RNA-binding protein Dnd1 inhibits microRNA access to target mRNA. Cell. 2007 Dec 28;131(7):1273-86. [Medline: 18155131] [doi: 10.1016/j.cell.2007.11.034]

75. Matin A. What leads from dead-end? Cell Mol Life Sci. 2007 Jun;64(11):1317-22. Review. [Medline: 17464447] [FREE Full Text] [doi: 10.1007/s00018-007-6433-3]

76. Youngren KK, Coveney D, Peng X, Bhattacharya C, Schmidt LS, Nickerson ML, Lamb BT, Deng JM, Behringer RR, Capel B, Rubin EM, Nadeau JH, Matin A. The Ter mutation in the dead end gene causes germ cell loss and testicular germ cell tumours. Nature. 2005 May 19;435(7040):360-4. [Medline: 15902260] [FREE Full Text] [doi: 10.1038/nature03595]

77. Liu X, Jiang L, Wang A, Yu J, Shi F, Zhou X. MicroRNA-138 suppresses invasion and promotes apoptosis in head and neck squamous cell carcinoma cell lines. Cancer Lett. 2009 Dec 28;286(2):217-22. Epub 2009 Jun 21. [Medline: 19540661] [FREE Full Text] [doi: 10.1016/j.canlet.2009.05.030]

78. Liu X, Yu J, Jiang L, Wang A, Shi F, Ye H, Zhou X. MicroRNA-222 regulates cell invasion by targeting matrix metalloproteinase 1 (MMP1) and manganese superoxide dismutase 2 (SOD2) in tongue squamous cell carcinoma cell lines. Cancer Genomics Proteomics. 2009 May-Jun;6(3):131-9. [Medline: 19487542] [FREE Full Text]

79. Kefas B, Godlewski J, Comeau L, Li Y, Abounader R, Hawkinson M, Lee J, Fine H, Chiocca EA, Lawler S, Purow B. microRNA-7 inhibits the epidermal growth factor receptor and the Akt pathway and is downregulated in glioblastoma. Cancer Res. 2008 May 15;68(10):3566-72. [Medline: 18483236] [FREE Full Text] [doi: 10.1158/0008-5472.CAN-07-6639]

80. Webster RJ, Giles KM, Price KJ, Zhang PM, Mattick JS, Leedman PJ. Regulation of epidermal growth factor receptor signaling in human cancer cells by microRNA-7. J Biol Chem. 2009 Feb 27;284(9):5731-41. Epub 2008 Dec 10. [Medline: 19073608] [FREE Full Text] [doi: 10.1074/jbc.M804280200]

81. Reddy SD, Ohshiro K, Rayala SK, Kumar R. MicroRNA-7, a homeobox D10 target, inhibits p21-activated kinase 1 and regulates its functions. Cancer Res. 2008 Oct 15;68(20):8195-200. [Medline: 18922890] [FREE Full Text] [doi: 10.1158/0008-5472.CAN-08-2103]

82. Jiang L, Liu X, Chen Z, Jin Y, Heidbreder CE, Kolokythas A, Wang A, Dai Y, Zhou X. MicroRNA-7 targets IGF1R (insulin-like growth factor 1 receptor) in tongue squamous cell carcinoma cells. Biochem J. 2010 Oct 25;432(1):199-205. [Medline: 20819078] [doi: 10.1042/BJ20100859]

83. Nakashima M, Kondo S, Shimizu Y, Wakisaka N, Murono S, Furukawa M, Yoshizaki T. Impact of MDM2 single nucleotide polymorphism on tumor onset in head and neck squamous cell carcinoma. Acta Otolaryngol. 2008 Jul;128(7):808-13. [Medline: 18568525$]$ [doi: $10.1080 / 00016480701724904]$

84. Magro PG, Russo AJ, Li WW, Banerjee D, Bertino JR. p14ARF expression increases dihydrofolate reductase degradation and paradoxically results in resistance to folate antagonists in cells with nonfunctional p53. Cancer Res. 2004 Jun 15;64(12):4338-45. [Medline: 15205349] [FREE Full Text] [doi: 10.1158/0008-5472.CAN-03-1045]

85. Obernosterer G, Leuschner PJ, Alenius M, Martinez J. Post-transcriptional regulation of microRNA expression. RNA. 2006 Jul;12(7):1161-7. Epub 2006 May 31. [Medline: 16738409] [FREE Full Text] [doi: 10.1261/rna.2322506] 
86. Piccinin S, Gasparotto D, Vukosavljevic T, Barzan L, Sulfaro S, Maestro R, Boiocchi M. Microsatellite instability in squamous cell carcinomas of the head and neck related to field cancerization phenomena. Br J Cancer. 1998 Nov;78(9):1147-51. [Medline: 9820170] [FREE Full Text] [doi: 10.1038/bjc.1998.644]

87. Hogg RP, Honorio S, Martinez A, Agathanggelou A, Dallol A, Fullwood P, Weichselbaum R, Kuo MJ, Maher ER, Latif $F$. Frequent $3 p$ allele loss and epigenetic inactivation of the RASSF1A tumour suppressor gene from region 3p21.3 in head and neck squamous cell carcinoma. Eur J Cancer. 2002 Aug;38(12):1585-92. [Medline: 12142046] [doi: 10.1016/S0959-8049(01)00422-1]

88. Wang S, Zhang R, Shu J, Lu Z, Zhu C, Chen X, Ge X. [Diagnostic value of ultrasonography in cervical lymph node metastasis]. Lin Chuang Er Bi Yan Hou Ke Za Zhi. 1999 Aug;13(8):352-3. Chinese. [Medline: 12541360]

89. Jiang L, Liu X, Kolokythas A, Yu J, Wang A, Heidbreder CE, Shi F, Zhou X. Downregulation of the Rho GTPase signaling pathway is involved in the microRNA-138-mediated inhibition of cell migration and invasion in tongue squamous cell carcinoma. Int J Cancer. 2010 Aug 1;127(3):505-12. [Medline: 20232393] [doi: 10.1002/ijc.25320]

90. Ridley AJ, Schwartz MA, Burridge K, Firtel RA, Ginsberg MH, Borisy G, Parsons JT, Horwitz AR. Cell migration: integrating signals from front to back. Science. 2003 Dec 5;302(5651):1704-9. Review. [Medline: 14657486] [doi: $10.1126 /$ science.1092053]

91. Wheeler AP, Ridley AJ. Why three Rho proteins? RhoA, RhoB, RhoC, and cell motility. Exp Cell Res. 2004 Nov 15;301(1):43-9. Review. [Medline: 15501444] [doi: 10.1016/j.yexcr.2004.08.012]

92. Ridley AJ. Rho proteins and cancer. Breast Cancer Res Treat. 2004 Mar;84(1):13-9. Review. [Medline: 14999150] [doi: 10.1023/B:BREA.0000018423.47497.c6]

93. Wu M, Wu ZF, Kumar-Sinha C, Chinnaiyan A, Merajver SD. RhoC induces differential expression of genes involved in invasion and metastasis in MCF10A breast cells. Breast Cancer Res Treat. 2004 Mar;84(1):3-12. [Medline: 14999149] [doi: 10.1023/B:BREA.0000018426.76893.21]

94. Fingleton B. Molecular targets in metastasis: lessons from genomic approaches. Cancer Genomics Proteomics. 2007 May-Jun;4(3):211-21. Review. [Medline: 17878524] [FREE Full Text]

95. Kleer CG, Teknos TN, Islam M, Marcus B, Lee JS, Pan Q, Merajver SD. RhoC GTPase expression as a potential marker of lymph node metastasis in squamous cell carcinomas of the head and neck. Clin Cancer Res. 2006 Aug 1;12(15):448590. [Medline: 16899593] [FREE Full Text] [doi: 10.1158/1078-0432.CCR-06-0376]

96. Clark EA, Golub TR, Lander ES, Hynes RO. Genomic analysis of metastasis reveals an essential role for RhoC. Nature. 2000 Aug 3;406(6795):532-5. Erratum in: Nature 2001 Jun 21;411(6840):974. [Medline: 10952316] [doi: $10.1038 / 35020106]$

97. Wong CC, Wong CM, Tung EK, Man K, Ng IO. Rho-kinase 2 is frequently overexpressed in hepatocellular carcinoma and involved in tumor invasion. Hepatology. 2009 May;49(5):1583-94. [Medline: 19205033] [doi: 10.1002/hep.22836]

98. Narumiya S, Tanji M, Ishizaki T. Rho signaling, ROCK and mDia1, in transformation, metastasis and invasion. Cancer Metastasis Rev. 2009 Jun;28(1-2):65-76. Review. [Medline: 19160018] [doi: 10.1007/s10555-008-9170-7]

\section{To cite this article:}

Kolokythas A, Miloro M, Zhou X. Review of MicroRNA Proposed Target Genes in Oral Cancer. Part II.

J Oral Maxillofac Res 2011;2(2):e2

URL: http://www.ejomr.org/JOMR/archives/2011/2/e2/v2n2e2ht.pdf

doi: $\underline{10.5037 / j o m r .2011 .2202}$

Copyright (C) Kolokythas A, Miloro M, Zhou X. Accepted for publication in the JOURNAL OF ORAL \& MAXILLOFACIAL RESEARCH (http://www.ejomr.org/), 19 April 2011.

This is an open-access article, first published in the JOURNAL OF ORAL \& MAXILLOFACIAL RESEARCH, distributed under the terms of the Creative Commons Attribution-Noncommercial-No Derivative Works 3.0 Unported License, which permits unrestricted non-commercial use, distribution, and reproduction in any medium, provided the original work and is properly cited. The copyright, license information and link to the original publication on (http://www.ejomr.org/) must be included. 